\title{
PROFIL KOMPETENSI SOSIAL GURU-GURU DI LINGKUNGAN YAYASAN TAMAN PENDIDIKAN DAN SOSIAL NAHDLATUL ULAMA KHADIJAH DAN PENGARUHNYA TERHADAP KEPEKAAN SOSIAL SD KHADIJAH SURABAYA
}

\author{
Mufidatus Shofiyah ${ }^{1}$, Warsono ${ }^{2}$ \\ ${ }^{1,2}$ Universitas Negeri Surabaya \\ wanda_sofia@yahoo.com ${ }^{1}$, warsono@unesa.ac.id ${ }^{2}$
}

\begin{abstract}
Abstrak
Tujuan penelitian ini untuk mendiskripsikan tentang profil kompetensi sosial guru-guru $\mathrm{SD}$, mendiskripsikan tentang kepekaan sosial siswa SD, mendiskripsikan tentang pengaruh kompetensi sosial guru-guru terhadap kepekaan sosial siswa SD di lingkungan Yayasan Taman Pendidikan dan Sosial Nahdlatul Ulama (YTPS-NU) Khadijah Surabaya. Metode dalam penelitian ini adalah deskriptif kuantitatif, jenis penelitian ini adalah non-eksperimen. Sampel penelitaian sebanyak 60 guru dan 360 siswa.

Hasil penelitian ini mendeskripsikan; (1) Ada perbedaan tingkat kompetensi sosial guruguru di YPTS-NU Khadijah Surabaya yaitu SD Khadijah rata-rata 89,35; SD Khadijah 3 rata-rata 85,95 dan SD Khadijah Pandegiling rata-rata 81,75, (2) Ada perbedaan tingkat kepekaan sosial siswa di sekolah YTPS-NU Khadijah, SD Khadijah dengan rata-rata 82,46, SD Khadijah 3 dengan rata-rata 81,72, SD Khadijah Pandegiling dengan rata-rata 81,52, dan ada perbedaan tingkat kepekaan sosial siswa kelas III, IV, dan V di tiga sekolah YTPS-NU Khadijah, rata-rata kepekaan sosial siswa kelas III adalah 79,18, rata-rata kepekaan sosial siswa kelas IV adalah 82,19 dan ratarata kepekaan sosial siswa kelas V adalah 84,33 dan (4) Terdapat korelasi kompetensi sosial guru terhadap kepekaan sosial siswa, artinya semakin tinggi kompetensi sosial guru, maka semakin tinggi kepekaan sosial siswa, dan semakin tinggi level kelas, maka semakin tinggi tingkat kepekaan sosial siswa.
\end{abstract}

Kata Kunci: kompetensi sosial guru, kepekaan sosial siswa, guru SD YTPS-NU Khadijah

\section{Abstract}

The purpose of this study is to describe the social competency profile of elementary school teachers, describe the social sensitivity of elementary school students, describe the influence of social competence of teachers on the social sensitivity of elementary students in the Nahdlatul Ulama Education and Social Foundation (YTPS-NU) Khadijah Surabaya. The method in this study is descriptive quantitative, this type of research is non-experimental. The research samples were 60 teachers and 360 students.

The results of this study describe; (1) There are differences in the level of social competence of teachers in YPTS-NU Khadijah Surabaya, namely SD Khadijah, on average 89.35; SD Khadijah 3 averaged 85.95 and SD Khadijah Pandegiling averaged 81.75, (2) There were differences in the level of social sensitivity of students in the YTPS-NU Khadijah school, SD Khadijah with an average of 82.46, SD Khadijah 3 with an average of 81.72, SD Khadijah Pandegiling with an average of 81.52, and there were differences in the level of social sensitivity of students in class III, IV, and V in three YTPS-NU Khadijah schools, the social sensitivity average of class III students was 79,18 , the average social sensitivity of class IV students is 82.19 and the social sensitivity average of class $V$ students is 84.33 and (4) There is a correlation of teacher social competencies towards students' social sensitivity, meaning that the higher the teacher's social competence, then the higher the social sensitivity of students, and the higher the level of the class, the higher the level of social sensitivity of students.

Keywords: teacher social competence, social sensitivity of students, elementary school teacher YTPS-NU Khadijah 


\section{PENDAHULUAN}

Pendidikan adalah usaha sadar dan terencana untuk mewujudkan suasana belajar dan proses pembelajaran agar peserta didik secara aktif mengembangkan potensi dirinya untuk memiliki kekuatan spiritual keagamaan, pengendalian diri, kepribadian, kecerdasan, akhlak mulia, serta keterampilan yang diperlukan dirinya, masyarakat, bangsa dan Negara (Undang-Undang Sistem Pendidikan Nasional (SISDIKNAS) No 20 Tahun 2003, n.d.). Guru sebagai salah satu bagian dari pendidik profesional memiliki tugas utama mendidik, mengajar, membimbing, mengarahkan, melatih, menilai, dan mengevaluasi peserta didik pada pendidikan anak usia dini jalur pendidikan formal, pendidikan dasar, dan pendidikan menengah. Salah satu kompetensi yang dimiliki guru adalah kompetensi sosial. Kompetensi sosial yang meliputi kemampuan berkomunikasi dan berinteraksi secara efektif dengan peserta didik, sesama pendidik, tenaga kependidikan, orang tua/wali peserta didik, dan masyarakat (Suhandani \& Kartawinata, 2014).

Guru memiliki peran yang sangat besar bagi siswa sekolah dasar. Guru adalah panutan bagi anak-anak di sekolah. Sekolah merupakan salah satu tempat dalam membentuk karakter siswa sehingga siswa akan memiliki kepribadian yang baik (Widyaningrum, 2016). Fenomena-fenomena yang sering terjadi di lingkungan Sekolah sebagai akibat kurangnya kepekaan guru di sekolah yakni sering terjadi perkelahian antar siswa, siswa sering melanggar tata terib sekolah, tidak sopan terhadap (teman, guru dan orang tua), berbicara kotor dengan teman dan sering bersikap egois. Hal itu merupakan bukti ketidak berhasilan guru untuk membentuk siswa menjadi manusia yang berkarakter dan peka terhadap lingkungan sekitarnya.

Dalam pendidikan "multikultural" ada beberapa langkah penting untuk diterapkan oleh para guru dalam menumbuhkan sikap kepedulian sosial siswa. Pertama, dalam pendidikan multikultural seorang guru sebaiknya mempunyai wawasan yang cukup tentang berbagai macam fenomena sosial yang ada di lingkungan murid-muridnya. Kedua, guru sebaiknya mempunyai sensitivitas terhadap adanya diskriminasi dan ketidakadilan sosial, ekonomi dan politik. Ketiga, seorang guru sebaiknya dapat menerapkan secara langsung sikap peduli dan anti-diskriminasi sosial, politik, dan ekonomi di kelas, sekolah, maupun di luar sekolah.

Guru merupakan sosok yang diteladani siswa. Dalam pelaksanaan proses pembelajaran, guru diharapkan mampu melakukan hubungan sosial yang baik dengan siswa melalui interaksi dan komunikasi. Kompetensi sosial yang dimiliki oleh guru akan berdampak pada kepekaan sosial siswa. Penelitian ini sejalan dengan penelitian (Ashsiddiqi, 2012) kompetensi sosial guru mengarahkan siswa untuk memiliki kecerdasan sosial yang dapat diaplikasikan dalam kehidupan sehari. Perbedaan penelitian ini dengan penelitian terdahulu yakni mendiskripsikan kompetensi sosial guru dari tiga sekolah dan menjelaskan pengaruh kompetensi sosial guru-guru terhadap kepekaan sosial siswa SD. Adapun tujuan penelitian ini adalah mendiskripsikan tentang profil kompetensi sosial guru-guru SD, mendiskripsikan tentang kepekaan sosial siswa SD, mendiskripsikan tentang pengaruh kompetensi sosial guru-guru terhadap 
kepekaan sosial siswa SD di lingkungan Yayasan Taman Pendidikan dan Sosial Nahdlatul Ulama (YTPS-NU) Khadijah Surabaya.

\section{METODE PENELITIAN}

Penelitian ini menggunakan pendekatan kuantitatif. Dalam menganalisis hubungan antarvariabel, dilakukan melalui analisis statistik. Penelitian ini merupakan penelitian non eksperimen (operation Research) dengan jenis penelitian survei karena mencari informasi faktual dari respondennya dengan menggunakan angket atau kuisioner guna melengkapi data. Penelitian ini diadakan di tiga sekolah dasar YTPSNU Khadijah Surabaya pada kelas III, IV dan V, yang meliputi SD Khadijah yang terletak di Jl. A. Yani $2-4$ Surabaya Kecamatan Wonokromo, SD Khadijah 3 yang terletak di Jl. Raya Lontar Candi Lempung 2-4 Manukan Kulon, Kecamatan Tandes dan SD Khadijah Pandegiling yang terletak di Jl. Pandegiling 217 Kecamatan Tegalsari. Kondisi siswa di sekolah ini rata-rata dari kalangan kelas menengah ke atas yang secara ekonomi mampu dan semua siswa beragama Islam. Waktu penelitian adalah semester ganjil tahun pelajaran 2017/2018 antara bulan Juli sampai Desember 2018.Sampel dalam penelitian ini adalah guru dan siswa kelas III, IV dan V dari 3 sekolah dibawah naungan YTPS-NU Khadijah Surabaya.

Tabel 1. Sampel Penelitian

\begin{tabular}{clcc}
\hline \multirow{2}{*}{ No } & \multicolumn{2}{|c}{ Lokasi } & \multicolumn{2}{c}{ Sampel } \\
\cline { 3 - 4 } & & Guru & Siswa \\
\hline 1 & SD Khadijah & 20 & 120 \\
\hline 2 & SD Khadijah 3 & 20 & 120 \\
\hline 3 & SD Khadijah Pandegiling & 20 & 120 \\
\hline \multicolumn{2}{c}{ Jumlah } & 60 & 360 \\
\hline
\end{tabular}

Teknik pengumpulan data yang digunakan dalam penelitian ini adalah angket. Angket yang digunakan dalam penelitian ini adalah angket tertutup, yang sudah disediakan jawabannya sehingga responden tinggal memilih (Purwanti, Suryawati, \& Ahmad, 2016). Uji validitas dilakukan dengan cara menghitung skor masing-masing butir pernyataan dengan skor total (keseluruhan butir pernyataan). Perhitungan yang peneliti lakukan dalam penelitian ini dalam mencari validitas butir pernyataan adalah dengan menggunakan program perhitungan statistik program SPSS 20.00 for windows dimana hasilnya (Corrected Item-Total Correlation) dibandingkan dengan angka kritis yang ada pada tabel kritis Momen Pearson (tabel angka kritis nilai r yaitu N-2) sesuai dengan derajat kebebasan dan tingkat signifikansinya.

Suatu data dapat dikatakan valid apabila nilai item koefisien korelasinya lebih besar dari nilai angka kritis yang ada pada tabel angka kritis Momen Pearson. Pengujian reliabilitas untuk mengetahui keajekan atau keterandalan alat pengumpul data penelitian (instrumen). Pengujian reliabilitas dapat dilakukan secara eksternal. Dalam penelitian ini untuk mengetahui reliabilitas setiap variabel yang diteliti, diiukur dengan metode Alpha Cronbach dengan rumus: koefisien alpha yang ketentuannya apabila koefisien korelasi alpha lebih besar dari 0,60 
dapat dinyatakan bahwa instrumen penelitian yang digunakan adalah reliabel(Gaol, Khumaedi, \& Masrukan, 2017).

Perhitungan reliabilitas dilakukan dengan menggunakan program statistik program SPSS 20.00 for windows pada bagian hasil Reliability Cronbach. Analisis data dalam penelitian ini adalah menggunakan analisis inferensial yang didahului dengan uji normalitas, uji homogenitas dan analisis variance dengan perhitungan program SPSS 20.00 for windows. Pada analisis inferensial yang akan dilakukan adalah uji normalitas, uji homogenitas dan analisis variance.

\section{HASIL DAN PEMBAHASAN}

Hasil hasil uji validitas variable kompetensi sosial guru pada 44 responden dapat dilihat pada tabel 2 dibawah ini.

Tabel 2. Hasil Uji Validitas Kompetensi Sosial Guru

\begin{tabular}{cccccc}
\hline $\begin{array}{c}\text { No. } \\
\text { Soal }\end{array}$ & Nilai Validitas & Keterangan & $\begin{array}{c}\text { No. } \\
\text { Soal }\end{array}$ & Nilai Validitas & Keterangan \\
\hline 1 & 0,618 & Valid & 12 & 0,632 & Valid \\
\hline 2 & 0,461 & Valid & 13 & 0,562 & Valid \\
\hline 3 & 0,451 & Valid & 14 & 0,679 & Valid \\
\hline 4 & 0,599 & Valid & 15 & 0,461 & Valid \\
\hline 5 & 0,246 & Tidak Valid & 16 & 0,463 & Valid \\
\hline 6 & 0,201 & Tidak Valid & 17 & 0,537 & Valid \\
\hline 7 & 0,598 & Valid & 18 & 0,552 & Valid \\
\hline 8 & 0,511 & Valid & 19 & 0,555 & Tidak Valid \\
\hline 9 & 0,509 & Valid & 20 & 0,280 & Valid \\
\hline 10 & 0,301 & Valid & 21 & 0,490 & Valid \\
\hline 11 & 0,433 & Valid & 22 & 0,410 & Valid \\
\hline
\end{tabular}

Dari tabel diatas, dapat diketahui tingkat validitas untuk Kompetensi Sosial Guru (X) yang terdiri dari 23 butir pernyataan yang ternyata terdapat 3 pernyataan yang digugurkan atau dibuang karena terdapat nilai corrected itemtotal correlation di bawah angka kritik nilai 0,304 yaitu pada item nomor 5, 6 dan 20 sehingga terdapat 20 pernyataan yang dinyatakan valid.

Setelah dilakukan uji validitas variabel kepekaan sosial siswa kepada 37 responden, hasil uji validitas pada 37 responden dapat dilihat pada tabel 3.

Tabel 3. Hasil Uji Validitas Kepekaan Sosial Siswa

\begin{tabular}{|c|c|c|c|c|c|}
\hline No. Soal & $\begin{array}{c}\text { Nilai } \\
\text { Validitas }\end{array}$ & Keterangan & No. Soal & $\begin{array}{c}\text { Nilai } \\
\text { Validitas }\end{array}$ & Keterangan \\
\hline 1 & 0,597 & Valid & 26 & 0,602 & Valid \\
\hline 2 & 0,604 & Valid & 27 & 0,575 & Valid \\
\hline 3 & 0,451 & Valid & 28 & 0,537 & Valid \\
\hline 4 & 0,571 & Valid & 29 & 0,635 & Valid \\
\hline 5 & 0,466 & Valid & 30 & 0,273 & Tidak Valid \\
\hline 6 & 0,431 & Valid & 31 & 0,408 & Valid \\
\hline 7 & 0,285 & Tidak Valid & 32 & 0,435 & Valid \\
\hline 8 & 0,539 & Valid & 33 & 0,363 & Valid \\
\hline
\end{tabular}




\begin{tabular}{|c|c|c|c|c|c|}
\hline 9 & 0,400 & Valid & 34 & 0,397 & Valid \\
\hline 10 & 0,493 & Valid & 35 & 0,461 & Valid \\
\hline 11 & 0,683 & Valid & 36 & 0,571 & Valid \\
\hline 12 & 0,342 & Valid & 37 & 0,660 & Valid \\
\hline 13 & 0,649 & Valid & 38 & 0,498 & Valid \\
\hline 14 & 0,387 & Valid & 39 & 0,476 & Valid \\
\hline 15 & 0,453 & Valid & 40 & 0,639 & Valid \\
\hline 16 & 0,590 & Valid & 41 & 0,600 & Valid \\
\hline 17 & 0,694 & Valid & 42 & 0,558 & Valid \\
\hline 18 & 0,483 & Valid & 43 & 0,431 & Valid \\
\hline 19 & 0,329 & Valid & 44 & 0,573 & Valid \\
\hline 20 & 0,532 & Valid & 45 & 0,632 & Valid \\
\hline 21 & 0,609 & Valid & 46 & 0,626 & Valid \\
\hline 22 & 0,645 & Valid & 47 & 0,650 & Valid \\
\hline 23 & 0,411 & Valid & 48 & 0,571 & Valid \\
\hline 24 & 0,574 & Valid & 49 & 0,604 & Valid \\
\hline 25 & 0,574 & Valid & & & \\
\hline
\end{tabular}

Dari tabel diatas, dapat diketahui tingkat validitas untuk variabel Kepekaan Sosial Siswa (Y) yang terdiri dari 49 butir pernyataan yang ternyata 2 pernyataan yang digugurkan atau dibuang karena nilainya kurang dari $r$ tabel, sehingga hanya terdapat 47 pernyataan yang dinyatakan valid. Pernyataan yang digugurkan atau dibuang pada item tersebut yaitu 7 dan 30 karena terdapat nilai corrected itemtotal correlation di bawah angka kritik nilai 0,334 .

Suatu variabel dikatakan reliabel jika memberikan nilai Cronbach Alpha > 0,60. Dari hasil uji reliabilitas kedua variabel dengan menggunakan SPSS 23 for windows 2007. Hasil uji reliabilitas angket Kompetensi Sosial Guru (X) mempunyai tingkat koefisien reliabilitas (reliability coefficients) sebesar 0,732 lebih besar dari >0,6. Dengan demikian angket ini reliabel. Sedangkan uji reliabilitas dari variabel kepekaan sosial siswa (Y) tersebut menghasilkan tingkat koefisien reliabilitas (reliability coefficients) sebesar 0,746 lebih besar dari > 0,6. Sehingga instrumen ini reliable. Hasil uji reliabilitas dapat dilihat pada tabel 4.3 dibawah ini.

Berdasarkan hasil perhitungan analisis variance pada SD Khadijah dapat diketahui bahwa rata-rata kompetensi sosial guru 89,35, dari tabel tersebut diperoleh nilai signifikasi sebesar 0,229 artinya sekolah ini memiliki nilai signifikasi > 0,05, maka dapat disimpulkan bahwa nilai berdistribusi normal. Pada SD Khadijah 3 dapat diketahui bahwa rata-rata kompetensi sosial guru di sekolah ini adalah 85,95, nilai signifikasinya pada kolom shapirov wilk adalah 0,099. Artinya sekolah ini memiliki signifikasi > 0,05, maka dapat disimpulkan bahwa nilai berdistribusi normal. Sedangkan pada SD Khadijah Pandegiling, rata-rata kompetensi sosial guru di sekolah ini adalah 81,75 dan nilai signifikasinya pada kolom shapirov wilk adalah 0,889. Artinya sekolah ini memiliki signifikasi >0,05, maka dapat disimpulkan nilai berdistribusi normal.

Berdasarkan hasil perhitungan analisis variance pada SD Khadijah dapat diketahui bahwa rata-rata kepekaan sosial siswa kelas III adalah 80,13, dari tabel 
tersebut diperoleh nilai signifikasi sebesar 0,065 artinya kepekaan sosial siswa kelas III di sekolah ini memiliki nilai signifikasi > 0,05, maka dapat disimpulkan bahwa nilai berdistribusi normal. Pada kelas IV dapat diketahui bahwa rata-rata kepekaan sosial siswa di sekolah ini adalah 82,63, nilai signifikasinya pada kolom shapirov wilk adalah 0,078. Artinya kepekaan sosial siswa di kelas IV ini memiliki signifikasi >0,05, maka dapat disimpulkan bahwa nilai berdistribusi normal. Sedangkan pada kelas V, rata-rata kepekaan sosial siswa di sekolah ini adalah 84,63 dan nilai signifikasinya pada kolom shapirov wilk adalah 0,199. Artinya kepekaan sosial siswa di kelas $\mathrm{V}$ ini memiliki signifikasi >0,05, maka dapat disimpulkan nilai berdistribusi normal.

Berdasarkan hasil perhitungan analisis variance pada SD Khadijah 3, dapat diketahui bahwa rata-rata kepekaan sosial siswa kelas III adalah 78,00 dari tabel tersebut diperoleh nilai signifikasi sebesar 0,054 artinya kepekaan sosial siswa kelas III di sekolah ini memiliki nilai signifikasi > 0,05, maka dapat disimpulkan bahwa nilai berdistribusi normal. Pada kelas IV dapat diketahui bahwa rata-rata kepekaan sosial siswa di sekolah ini adalah 82,55, nilai signifikasinya pada kolom shapirov wilk adalah 0,080. Artinya kepekaan sosial siswa di kelas IV ini memiliki signifikasi >0,05, maka dapat disimpulkan bahwa nilai berdistribusi normal. Sedangkan pada kelas V, rata-rata kepekaan sosial siswa di sekolah ini adalah 84,62 dan nilai signifikasinya pada kolom shapirov wilk adalah 0,100. Artinya kepekaan sosial siswa di kelas V ini memiliki signifikasi >0,05, maka dapat disimpulkan nilai berdistribusi normal.

Berdasarkan hasil perhitungan analisis variance pada SD Khadijah Pandegiling, dapat diketahui bahwa rata-rata kepekaan sosial siswa kelas III adalah 79,40 dari tabel tersebut diperoleh nilai signifikasi sebesar 0,080 artinya kepekaan sosial siswa kelas III di sekolah ini memiliki nilai signifikasi > 0,05, maka dapat disimpulkan bahwa nilai berdistribusi normal. Pada kelas IV dapat diketahui bahwa rata-rata kepekaan sosial siswa di sekolah ini adalah 81,40, nilai signifikasinya pada kolom shapirov wilk adalah 0,396. Artinya kepekaan sosial siswa di kelas IV ini memiliki signifikasi > 0,05, maka dapat disimpulkan bahwa nilai berdistribusi normal. Sedangkan pada kelas V, rata-rata kepekaan sosial siswa di sekolah ini adalah 83,75 dan nilai signifikasinya pada kolom shapirov wilk adalah 0,121. Artinya kepekaan sosial siswa di kelas V ini memiliki signifikasi >0,05, maka dapat disimpulkan nilai berdistribusi normal.

Berdasarkan hasil perhitungan analisis variance pada kelas III SD, dapat diketahui bahwa rata-rata kepekaan sosial siswa 80,13, dari tabel tersebut diperoleh nilai signifikasi sebesar 0,065 artinya sekolah ini memiliki nilai signifikasi > 0,05, maka dapat disimpulkan bahwa nilai berdistribusi normal. Pada kelas III SD Khadijah 3 dapat diketahui bahwa rata-rata kepekaan sosial siswa di sekolah ini adalah 78,00 nilai signifikasinya pada kolom shapirov wilk adalah 0,064 . Artinya kepekaan sosial siswa kelas III di sekolah ini memiliki signifikasi $>0,05$, maka dapat disimpulkan bahwa nilai berdistribusi normal. Sedangkan 
pada SD Khadijah Pandegiling, rata-rata kepekaan sosial siswa kelas III di sekolah ini adalah 79,40 dan nilai signifikasinya pada kolom shapirov wilk adalah 0,070. Artinya kepekaan sosial kelas III di sekolah ini memiliki signifikasi >0,05, maka dapat disimpulkan nilai berdistribusi normal.

Berdasarkan hasil perhitungan analisis variance pada kelas IV SD Khadijah, dapat diketahui bahwa rata-rata kepekaan sosial siswa 82,63, dari tabel tersebut diperoleh nilai signifikasi sebesar 0,058 artinya sekolah ini memiliki nilai signifikasi > 0,05, maka dapat disimpulkan bahwa nilai berdistribusi normal. Pada kelas IV SD Khadijah 3 dapat diketahui bahwa rata-rata kepekaan sosial siswa di sekolah ini adalah 82,55 nilai signifikasinya pada kolom shapirov wilk adalah 0,108. Artinya kepekaan sosial siswa kelas IV di sekolah ini memiliki signifikasi > 0,05, maka dapat disimpulkan bahwa nilai berdistribusi normal. Sedangkan pada SD Khadijah Pandegiling, rata-rata kepekaan sosial siswa kelas IV di sekolah ini adalah 81,40 dan nilai signifikasinya pada kolom shapirov wilk adalah 0,396. Artinya kepekaan sosial kelas IV di sekolah ini memiliki signifikasi >0,05, maka dapat disimpulkan nilai berdistribusi normal.

Berdasarkan hasil perhitungan analisis variance pada kelas V SD Khadijah, dapat diketahui bahwa rata-rata kepekaan sosial siswa 84,63, dari tabel tersebut diperoleh nilai signifikasi sebesar 0,199 artinya sekolah ini memiliki nilai signifikasi > 0,05, maka dapat disimpulkan bahwa nilai berdistribusi normal. Pada kelas V SD Khadijah 3 dapat diketahui bahwa rata-rata kepekaan sosial siswa di sekolah ini adalah 84,62 nilai signifikasinya pada kolom shapirov wilk adalah 0,053. Artinya kepekaan sosial siswa kelas V di sekolah ini memiliki signifikasi > 0,05, maka dapat disimpulkan bahwa nilai berdistribusi normal. Sedangkan pada SD Khadijah Pandegiling, rata-rata kepekaan sosial siswa kelas V di sekolah ini adalah 83,75 dan nilai signifikasinya pada kolom shapirov wilk adalah 0,121. Artinya kepekaan sosial kelas V di sekolah ini memiliki signifikasi >0,05, maka dapat disimpulkan nilai berdistribusi normal.

Rata-rata kepekaan sosial siswa kelas III, IV dan V di masing-masing sekolah ada peningkatan. Di SD Khadijah rata-rata kepekaan sosial siswa kelas III adalah 80,13, kelas IV rata-rata kepekaan sosial siswa 82,63 dan kelas V rata-rata kepekaan sosial siswa 84,63. Dari ketiga level kelas tersebut, rata-rata kepekaan sosial siswa di sekolah ini adalah 82,46. Di SD Khadijah 3, rata-rata kepekaan sosial siswa di kelas III adalah 78,00, kelas IV rata-rata kepekaan sosial siswanya 82,55 dan kelas V rata-rata kepekaan sosial siswanya 84,62. Rata-rata kepekaan sosial siswa di sekolah ini adalah 81,72. Sedangkan di sekolah SD Khadijah Pandegiling, rata-rata kepekaan sosial siswa kelas III adalah 79,40, kelas IV ratarata kepekaan sosial siswa adalah 81,40 dan kelas V rata-rata kepekaan sosial siswa adalah 83,75. Dari ketiga level kelas tersebut, rata-rata kepekaan sosial siswa di sekolah ini adalah 81,52.

Rata-rata kompetensi sosial guru di SD Khadijah adalah 89,35, di SD Khadijah 3 rata-rata kompetensi sosial guru adalah 85,95 dan rata-rata kompetensi 
sosial guru di SD Khadijah Pandegiling adalah 81,75. Jika kepekaan sosial siswa kelas III, IV dan V di tiga sekolah tersebut dibandingkan, maka rata-rata tertinggi adalah SD Khadijah yaitu 82,46, urutan kedua SD Khadijah 3 dengan rata-rata 81,72 dan urutan ketiga adalah SD Khadijah Pandegiling dengan rata-rata 81.52. Hal tersebut sejalan dengan hasil rata-rata kompetensi sosial guru, yang mana rata-rata tertinggi adalah SD Khadijah yaitu 89, 35, kedua adalah SD Khadijah 3 dengan rata-rata 85,95 dan ketiga adalah SD Khadijah Pandegiling dengan ratarata 81,75. Sehingga, dengan demikian ada korelasi antara kompetensi sosial guru dan kepekaan sosial siswa. Hal ini sejalan dengan penelitian (Hasyim, Sidoarjo, \& Diayuningsih, 2014) yang menyatakan bahwa pembentukan karakter siswa dipengaruhi oleh keteladanan dari guru.

Kepekaan sosial siswa jika diamati setiap levelnya di tiga sekolah tersebut juga mengalami peningkatan. Rata-rata kepekaan sosial siswa kelas III di tiga sekolah adalah 79,18, rata-rata kepekaan sosial siswa kelas IV adalah 82,19 dan rata-rata kepekaan sosial siswa kelas V adalah 84,33. Semakin tinggi level kelas, maka kepekaan sosial siswa juga semakin tinggi. Dari analisis diskriptif dan uji statistik yang telah dilakukan, dapat ditarik sebuah kesimpulan bahwa semakin tinggi kompetensi sosial guru, maka semakin tinggi kepekaan sosial siswa dan semakin tinggi level kelas, maka semakin tinggi tingkat kepekaan sosial siswa, hal tersebut, karena siswa yang tinggi levelnya, mengalami proses pembelajaran yang lebih lama bila dibandingkan dengan siswa yang baru mengalami proses pembelajaran

\section{KESIMPULAN DAN SARAN}

Berdasarkan pembahasan hasil penelitian dapat ditarik kesimpulan sebagai berikut : (1) ada perbedaan tingkat kompetensi sosial guru-guru di YPTS-NU Khadijah Surabaya, berdasarkan rata-rata urutan tertinggi adalah SD Khadijah yaitu 89,35, kedua adalah SD Khadijah 3 dengan rata-rata 85,95 dan ketiga adalah SD Khadijah Pandegiling dengan rata-rata 81,75; (2) ada perbedaan tingkat kepekaan sosial siswa di sekolah-sekolah YTPS-NU Khadijah, rata-rata tertinggi yakni di SD Khadijah dengan rata-rata 82,46, kedua adalah SD Khadijah 3 dengan rata-rata 81,72 dan ketiga adalah SD Khadijah Pandegiling dengan rata-r ata 81,52 dan ada perbedaan tingkat kepekaan sosial siswa kelas III, IV, dan V di tiga sekolah-sekolah YTPS-NU Khadijah, rata-rata kepekaan sosial siswa kelas III adalah 79,18, rata-rata kepekaan sosial siswa kelas IV adalah 82,19 dan rata-rata kepekaan sosial siswa kelas V adalah 84,33. (3) Terdapat pengaruh kompetensi sosial guru terhadap kepekaan sosial siswa. Dimana bentuk pengaruhnya adalah positif, artinya semakin tinggi kompetensi sosial guru di suatu sekolah, maka semakin tinggi pula kepekaan sosial siswa, dan semakin tinggi level kelas, maka semakin tinggi tingkat kepekaan sosial siswa.

Berdasarkan kesimpulan seperti yang dipaparkan disarankan hal-hal sebagai berikut: (1) kompetensi sosial guru tidak kalah penting dengan 
kompetensi-kompetensi yang lain yang harus dikuasai seorang guru. Oleh karenanya, dalam seleksi penerimaan calon guru, perlu kiranya kompetensi sosial ini juga menjadi pertimbangan sebagai suatu syarat diterima sebagai seorang guru; (2) kita dapat menciptakan situasi sekolah, dimana semua pimpinan, guru dan tata usaha menjadi tauladan, berperilaku disiplin, bersikap sopan, berbicara santun, menjaga kebersihan, membuang sampah ke tempat sampah, dan sebagainya; (3) perlu adanya peningkatan kompetensi sosial seperti kemampuan guru untuk berkomunikasi dan bergaul secara efektif dengan siswa, sesama guru, tenaga kependidikan, orang tua atau wali murid dan masyarakat sekitar agar dapat meningkatkan kepekaan sosial siswa.

\section{DAFTAR RUJUKAN}

Ashsiddiqi, H. (2012). Kompetensi Sosial Guru Dalam Pembelajaran Dan Pengembangannya. Ta'dib: Journal of Islamic Education (Jurnal Pendidikan Islam), $\quad$ 17(01), 61-71. $\quad$ Retrieved from http://jurnal.radenfatah.ac.id/index.php/tadib/article/view/25

Gaol, P. L., Khumaedi, M., \& Masrukan, M. (2017). Pengembangan Instrumen Penilaian Karakter Percaya Diri pada Mata Pelajaran Matematika Sekolah Menengah Pertama. Journal of Educational Research and Evaluation, 6(1), 63-70. https://doi.org/10.15294/JRER.V6I1.16209

Hasyim, W., Sidoarjo, T., \& Diayuningsih, I. (n.d.). POLA PENGEMBANGAN NILAI-NILAI KARAKTER MELALUI KULTUR SEKOLAH DI SMA Totok Suyanto Abstrak, 094254213, 31-45.

Purwanti, S., Suryawati, E., \& Ahmad, D. (2016). the Capacity To Think Critical Student Class Seed X Man 2 Model Pekanbaru in Learning Biology Academic Kemampuan Berpikir Kritis Siswa Unggulan Kelas X Man 2 Model Pekanbaru Pada Pembelajaran Biologi Tahun Ajaran 2015 / 2016, 113.

Suhandani, D., \& Kartawinata, J. (2014). Identifikasi Kompetensi Guru Sebagai Cerminan Profesionalisme Tenaga Pendidik Di Kabupaten Sumedang (Kajian Pada Kompetensi Pedagogik). Mimbar Sekolah Dasar, 1(2). https://doi.org/10.17509/mimbar-sd.v1i2.874

Undang-Undang Sistem Pendidikan Nasional (SISDIKNAS) No 20 Tahun 2003. (n.d.).

Widyaningrum, R. (2016). Pembentukan Karakter Peduli Lingkungan Siswa Sekolah Dasar Melalui Sekolah Peduli dan Berbudaya Lingkungan. Widya Wacana, 11(1), 108-115. 